\title{
The Relevance of Basic Sciences and Common Technical Courses in Undergraduate Agricultural Curricula in Kenya
}

\author{
Mary C. Lopokoiyit \\ Email: mclopokoiyit@yahoo.com \\ Tel: 0724-313771
}

Prof. Christopher Onyango

Email: onyangochristopher6@gmail.com

Tel: 0722-902908

\author{
Dr. Joash K. Kibett \\ Email: kibettjoash@yahoo.com /jkibett@egerton.ac.ke \\ Tel: $0726-097186$ \\ Department of Agricultural Education and Extension, \\ P.O. Box 20115-536, Egerton University
}

Doi:10.5901/ajis.2013.v2n2p71

\section{Abstract}

Achieving balance between basic sciences, extension methodology and technical subject matter in the pre-service curriculum for agricultural extension staff has been a challenge in the process of curriculum reform. This study sought to determine the adequacy of basic sciences and common technical courses in the undergraduate agricultural curricula through a training needs analysis of 440 extension staff in the public and private agricultural extension service sector. The study also explored differences in training needs between Front line Extension Worker (FEW) and Subject Matter Specialists (SMS). A crosssectional survey was used and training need were determined and prioritized using Borich's Needs Discrepancy Model (BNDM) using a Mean Weighted Discrepancy Score (MWDS). The basic sciences with the highest training needs were Basic Computer applications, Research Methods and Seminars while the common technical courses with the highest training need were Agricultural Law, Financial and Human resource management and Rural Development. In the basic sciences only Basic computer applications yielded significant differences between the training needs of Public and Private extension agents and between FEW and SMS. Significant differences in the MWDS ratings of Public and Private Extension Agents were obtained in; Agricultural Economics, Principles of Marketing, Engineering/Technical Drawing and Workshop Technology. Respondents from the Public sector had higher MWDS ratings indicating greater training needs than those from the Private sector. Between FEW and SMS, Field Attachment, Engineering/Technical drawing and Extension Education courses were significantly different. All the basic and common technical courses had positive MWDS warranting their inclusion in the undergraduate agriculture curricula. This also implies that there is need to review the content and instructional methodology to ensure the relevance of these courses as core prerequisites that provide basic information and foster critical skills necessary to the understanding of technical courses in the various areas of specialization in agriculture.

Keywords: Training needs, Basic sciences, Common technical courses, Undergraduate agricultural curricula, Agricultural extension

\section{Introduction}

The first step in curriculum development is needs assessment that legitimizes all other processes in curriculum development such as the selection of content, learning experiences and evaluation (Gagne and Briggs, 1979; Miller and Seller, 1985; Tanner and Tanner, 1980; Tyler, 1949). According to Gagne and Briggs (1979), perceived needs fall into three types: 
a. a need to conduct instruction more effectively and efficiently for a course which is already a part of the curriculum,

b. a need to revitalize both the content and the method for an existing course or,

c. a need to develop a new course.

They argue that as the tempo of change in society increases, educational needs should be reviewed more frequently to reduce the lag between actual and needed curricula. The focus on relevance in extension education whereby students acquire the skills, knowledge and attitudes that are being demanded by governments and private employers' results in a curriculum that is competency based. According to Lentz (1983) and Waters and Haskell (1988), the purpose of identifying needs is to build a foundation for providing relevant education and such identification will assist in establishing priorities and designing activities. For curriculum developers responsible for comprehensive development of educational program upon which successive educational and training are developed, TNA provides a basis for setting objectives justifying and evaluating the curriculum based on identified needs from various sources; society, subject matter and learners (Gagne and Briggs, 1979; Miller and Seller, 1985) (Crowder et al., 1999). TNA provides a basis for setting objectives justifying and evaluating the curriculum based on identified needs from various sources; society, subject matter and learners (Gagne and Briggs, 1979; Miller and Seller, 1985). TNA has been used to develop and improve extension program for extension clients, farmers and communities (Bazik \& Feltes, 1999; Bowe et al, 1999; Mwangi \& Asiabaka, 2001; Neito et al, 1997). This study sought to use the tools developed in TNA to identify training needs of extension agents with reference to the undergraduate agricultural program in order to identify those aspects in the curriculum that are still relevant and new areas that are required. Borich's Needs Discrepancy Model (BNDM), consisting of three ratings, an importance rating, knowledge rating and opportunity of use rating that allows data to be weighted and ranked in order of priority (Borich, 1980). Many needs assessment models do not allow for prioritization of needs (Edwards and Briers, 1999; Joerger, 2002) but by calculation of a Mean Weighted Discrepancy Score (MWDS) for each competency and dividing the sum of weighted discrepancy scores by the number of observations the Borich method enables this to be done. The MWDS are then ranked from the highest to the lowest and this corresponds to the level of need. According to Joerger (2002), Borich's model can be used to compare training needs within and between different groups by subjecting the median scores and MWDS to further analyses. This study sought to use the tools developed in TNA to identify training needs of extension agents with reference to the basic science and common technical courses in the undergraduate agricultural program in order to identify those aspects in the curriculum that are still relevant and new areas that are required.

\section{Undergraduate Agricultural Curricula}

Good pre-service training enables individuals enter into service with confidence, competence and motivation and need relatively less induction and lengthy in-service training, leading to savings in terms of time, energy and cost. This consequently, results in improved performance and output of extension organization due to better contribution of individual employees from the very beginning (Qamar, 1997). Traditionally, academic program and curricula are conceived, developed and controlled by universities and colleges with very little or no input from stakeholders (Rogers and Taylor, 1998; Taylor, 1998) resulting in agricultural program that are not responsive to the needs of the extension personnel lowering the quality of teaching (Crowder et al, 1999; Pretty, 1995; Pretty and Chambers, 1993; Zinna et. al, 1997).

There have been initiatives to develop responsive training program for the revitalization of the agricultural extension profession world wide and in sub-Saharan Africa. Hawkesbury agricultural college, Australia like other agricultural institutions are facing challeges of falling student enrolments, diminishing graduate employment prospects and declining community and political support with corresponding decline in funding (Bawden, 1996; FAO, 1991; Pretty, 1995). Under the Sasakawa Africa Fund for Extension Education (SAFE) curricula reform were instituted at the University of Cape Coast in Ghana and Alemaya University of Agriculture in Ethiopia. The main focus of SAFE was the training of mid-career extension staff working with ministries of agriculture and NGOs engaged in agricultural and rural development and involved revitalization of the agricultural extension by upgrading experienced mid-career extension staff to earn a BSc degree in agricultural extension. The institutions were helped to increase their flexibility, develop client-driven training program, acquire relevant core instructional materials, forge partnerships and linkages and mobilize internal resources both human and financial to sustain their program (Crowder et. al, 1999). Curriculum reform were based on philosophical changes in methodology, learning experiences and increasing interaction among students, teaching staff and the 
community and institutional management. The curricula design focused on participatory extension method, multidisciplinary team teaching, systems theories and philosophies that reflect the complex issues that characterize rural and agricultural development. Emphasis was also placed on the linkages between basic and applied science, between research, education and extension, and between people, the environment, sustainable agricultural production and rural development (Crowder et al, 1999; FAO, 1991; Lindley, 1999; Pretty, 1995; Pretty and Chambers, 1993; Zinna et. al. 1997).

A key challenge in curricula reform is achieving balance between extension methodology and technical subject matter in the pre-service curriculum for extension field staff has also been a challenge in the process of curriculum reform. Extension methodology should include internship and SEP along with the technical subjects in agriculture. Unfortunately, agricultural extension is marginalized in agricultural universities and colleges, especially in Africa, with only a negligible number of credit hours allocated to it and related courses. Lindley (1999) suggests that 20-25 percent of the curriculum should be devoted to extension methods such as communication skills, extension approaches, organizing and maintaining groups, programme planning and evaluation and working with various extension clientele. Maxwell and Lindley (1999) propose that the curriculum to be balanced as follows; 10 per cent, Arts and Humanities; 15 per cent, Social and Behavioural sciences; 25 per cent, Natural Sciences and Mathematics and 50 per cent on courses pertaining to a selected professional option. In the B.Sc. agricultural extension curriculum developed at the University of Cape Coast, approximately one-half of the total credit points required to graduate are acquired from extension and extensionrelated courses. Traditional courses such as adult education, extension methodology, programme planning and evaluation and contemporary issues such as critical thinking, oral and written communication skills, food security and the relationship between population and food production were included. About ten percent of the credit hours in agricultural education and extension programme at Egerton University are allocated to extension and although this has practical component the study sought to investigate the adequacy of basic and common technical courses offered in agricultural undergraduate programs in Kenya.

\section{Objectives and hypothesis of the study}

The main purpose of the study was to determine the training needs and perceptions of agricultural extension agents in public and private extension service toward basic and common technical courses in the agriculture undergraduate programs.

\subsection{Objectives}

1. There is no statistically significant difference in the training needs of basic courses between public and private agricultural extension agents.

2. There is no statistically significant difference in the training need of common technical courses between public and private agricultural extension agents.

\subsection{Research Design}

The study employed a cross-sectional survey design. This is because the characteristics that served as independent variables could not be directly controlled and the variables were being studied in retrospect and therefore could not be manipulated (Borg and Gall, 1989; Cohen and Manion, 1989 and Wiersma, 1995).

\subsection{Population and Sampling}

The target population for the study consisted of extension agents working with the national extension system and private extension providers. The national extension system comprises the Ministry of Agriculture and the Ministry Livestock and Fisheries Development in Kenya. There were approximately 3500 extension agents in the Ministry of Agriculture (MoA, 2004) and 1100 in the Ministry Livestock and Fisheries Development (MoLFD, 2004). These extension agents are distributed in the 71 districts and formed the sampling frame for the districts. Purposive sampling was considered appropriate for this stage of sampling to enable the study capture the requisite diverse national extension training needs that prevail in the various parts of the country. The study sample was drawn from four provinces and covered a total of 
eighteen districts in Kenya. Table 1 presents the geographical distribution of the respondents in the provinces and districts.

Table 1: Distribution of respondents by province

\begin{tabular}{lcc}
\hline Location of Study & Frequency & Percent \\
\hline Rift Valley Province & 153 & 34.8 \\
Coast Province & 89 & 20.2 \\
Eastern Province & 69 & 15.7 \\
Western Province & 129 & 29.3 \\
\hline Total & 440 & 100.0 \\
\hline
\end{tabular}

\subsection{Methodology and Instrumentation}

The Borich's Needs Discrepancy Model effectively lends itself to the standard survey questionnaire which was designed to solicit the perception of extension personnel toward basic and core technical courses. The first section of the questionnaire was designed to collect demographic data and to delineate characteristics of the respondents. Items in the second section were on a five point Likert scale indicating the level of importance, knowledge and opportunity use, enabling educational need to be calculated and prioritized. Each section had additional open-ended questions soliciting further views in the various items. The items were developed from a synthesis of the agricultural undergraduate curricula of universities in Kenya and a review of relevant literature and questionnaires in agricultural extension (Conklin et al., 2002; Edwards \& Briers 1999; FAO, 1996; Foster et al., 1995; ITA, 1997; Joerger, 2002; Lyles \& Warmbrod, 1997; Radhakrishna \& Martin, 1999; Odhingo, 1996; Ong'ondo, 1984; Waters \& Haskell, 1989; Williams, 1967).

\subsection{Reliability and Validity}

Face validity was done during the pilot test to ensure that the questionnaires were acceptable to respondents in terms of the format, length and clarity of expression while content validity was done to ensure that the instrument measures what was intended and that it captured the objectives of the study The instruments were pilot-tested in three sessions in Koibatek district. The comments and suggestions given were incorporated into the final questionnaire. Reliability was assessed using the Kuder- Richardson (K-R 21) formulae to determine the degree of consistency and accuracy of the instruments. in accordance with Borg and Gall (1989) and because the instruments are relatively long, the consistency of individual scores improved resulting in a reliability coefficient of 0.79 .

\section{Results and Discussions}

A total of 440 extension personnel responded to the training needs questionnaire. The public run extension service under the Ministry of Agriculture and the Ministry of Livestock Development accounted for 325 of the respondents while 115 respondents were employed in privately run extension service in research institutions and agro-based companies. Women constituted 29.5 percent of the respondents. In public sector it is envisioned that women form 30 percent of the wage labour. This compares favourably with the government statistics that indicate that female workers constitute $30 \%$ of the overall wage employment and they have the highest representation in educational services employment (45\%) (Economic Survey, 2007). This could also be attributed to efforts in gender mainstreaming in agriculture by the Ministry of Agriculture in line with Government policy. This compares favourably with Thailand and Trinidad where it was estimated that about $28 \%$ and $31 \%$ of field extension staff were female, irrespective of subject-matter area. This seems to be satisfactory compared to $22 \%$ and $14 \%$ in Nigeria and Syria respectively. 
Table 2: Demographic characteristics of respondents

\begin{tabular}{|c|c|c|c|}
\hline Demogr & ristic & Frequency & Percent \\
\hline Extensic & & & \\
\hline & Public service & 325 & 73.9 \\
\hline & Private & 115 & 26.1 \\
\hline & Research institutions & 50 & 11.3 \\
\hline & $N G O$ & 6 & 1.4 \\
\hline & Agro-based industry & 59 & 13.4 \\
\hline & Total & 440 & 100.0 \\
\hline Age & $<30$ & 40 & 9.1 \\
\hline & $31-40$ & 105 & 23.9 \\
\hline & $41-50$ & 254 & 57.7 \\
\hline & $51-60$ & 41 & 9.3 \\
\hline & Total & 440 & 100.0 \\
\hline Gender & Male & 310 & 70.5 \\
\hline & Female & 130 & 29.5 \\
\hline & Total & 440 & 100.0 \\
\hline
\end{tabular}

The respondents had a minimum qualification of a diploma in an agricultural discipline and who were categorised as front line workers (FEW) who constituted 61.6 percent of the respondents (Table 3). Subject Matter Specialists (SMS) had a minimum of a degree in an agricultural discipline and constituted 38.4 percent $(n=169)$. This indicates the high level of qualified personnel in agricultural extension that could be attributed to employers' commitment to professional development.

Table 3: Respondents qualifications and area of specialization

\begin{tabular}{|c|c|c|c|}
\hline \multirow{2}{*}{\multicolumn{2}{|c|}{ Professional Characteristic }} & Frequency & Percent \\
\hline & \multicolumn{3}{|c|}{ Category of respondent and Qualification } \\
\hline \multirow[t]{2}{*}{ FEW } & Diploma & 271 & 61.6 \\
\hline & & 169 & 38.4 \\
\hline \multirow[t]{4}{*}{ SMS } & Degree & 128 & 29.1 \\
\hline & Masters & 37 & 8.4 \\
\hline & $\mathrm{PhD}$ & 4 & 0.9 \\
\hline & Total & 440 & 100.0 \\
\hline \multicolumn{4}{|c|}{ Area of specialization } \\
\hline & General agriculture & 133 & 30.2 \\
\hline & Horticulture & 87 & 19.8 \\
\hline & Agricultural economics/ Agricultural business management & 49 & 11.1 \\
\hline & Agricultural engineering & 38 & 8.6 \\
\hline & Agricultural education and extension & 28 & 6.4 \\
\hline & Animal production/health & 39 & 8.9 \\
\hline & Agricultural and human ecology/Home economics & 46 & 10.4 \\
\hline & Sub-total & 420 & 95.4 \\
\hline \multicolumn{4}{|c|}{ Others } \\
\hline & Biochemistry & 1 & 0.2 \\
\hline & Applied biology & 2 & 0.5 \\
\hline & Analytical chemistry & 3 & 0.7 \\
\hline & Dairy technology & 5 & 1.1 \\
\hline & Sociology & 5 & 1.1 \\
\hline & Natural resources & 2 & 0.5 \\
\hline & Biotechnology & 1 & 0.2 \\
\hline & Environmental science & 1 & 0.2 \\
\hline & Sub total & 20 & 4.5 \\
\hline & Total & 440 & 100.0 \\
\hline
\end{tabular}




\begin{tabular}{|c|c|c|}
\hline \multicolumn{3}{|l|}{ Time spent on Responsibility } \\
\hline Administration & 290 & 15.0 \\
\hline Field work & 420 & 51.1 \\
\hline Seminars/workshops & 357 & 7.0 \\
\hline Extension/advisory & 372 & 11.5 \\
\hline Meeting & 395 & 9.6 \\
\hline Other responsibilities & 157 & 6.0 \\
\hline \multicolumn{3}{|l|}{ Staff under supervision } \\
\hline 0 & 104 & 23.6 \\
\hline $1-10$ & 246 & 55.9 \\
\hline $11-20$ & 58 & 13.2 \\
\hline $21-30$ & 13 & 3.0 \\
\hline $31-40$ & 9 & 2.0 \\
\hline 41 and more & 10 & 2.3 \\
\hline Total & 440 & 100.0 \\
\hline
\end{tabular}

The large number of diploma holders is a potential for in-service training to upgrade their qualifications. The highest level of qualifications was at PhD level $(n=4)$ and Masters level $(n=37)$. It appears that a functionally effective SMS to field extension agent ratio would be approximately 1 to $4-5$, or about $20 \%$ of SMSs with at least an M.Sc. degree, or equivalent training, and extensive field experience (FAO, 1990; FAO, 1996; Swanson, 2008).

In Thailand and Trinidad the SMS: field extension agent ratio (1:8), compared to Nigeria (1:27) and Syria (1:68), which seems quite high. The areas of specialization were wide to meet the requirements of diverse agriculture activities. According to Huerta and Smith (2001) agent specialization is conceptualized as a means of providing expertise closer to program delivery and as a way to improve the county agent's ability to work across county lines and across program lines. Of interest is the employment of extension agents in non-traditional fields such as Sociology and Environmental science. This is in recognition of the need for multidisciplinary approach in addressing the complexity of agricultural production systems as well as cross-cutting issues faced by both farmers and extension agents. Table 3 shows the respondents qualifications and the area of specialization.

\subsection{Training needs in the Basic Sciences}

Basic sciences in agricultural undergraduate curricula are core prerequisite courses that consist of basic science, mathematics, engineering, computer sciences course that provide basic information, foster critical skills and form prerequisites necessary to the understanding of technical courses in the various areas of specialization in agriculture. These courses are covered mainly in the first year of undergraduate study. The number of credit hours covered by these courses is quite substantial, 54 to 60 credit hours equivalent to 25 to 35 percent of total credit factors (Egerton University, 2008; University of Nairobi, 2008). The findings are similar to recommendations by Maxwell and Lindley (1999) that Natural Sciences and Mathematics ought to constitute 25 per cent weighting for agricultural undergraduate courses. The study sought to determine their relevance through training needs analysis. All the courses had positive MWDS obtained for all the courses (Table 4) implying that the respondents required training in all the courses. Although positive, the low MWDS scores imply that the importance ratings were high but the opportunity for use was low. This validates the presence and relevance of basic science courses in undergraduate agriculture curriculum.

The mean scores of importance, knowledge and opportunity to use were all positive resulting in a mean positive MWDS. This implies that all the basic science courses were important and the respondents required them for training. These courses also reflect the competencies that are necessary in the agricultural extension work. According to the respondents, the three most important basic sciences were Technical report writing, Communication skills and Basic Computer Applications. The basic sciences with the highest knowledge rating was Communication skills, Technical Report Writing, and Seminars. The positive knowledge rating reflects the competency level of the respondents and could be an indicator of continuing training in these areas through in-service training and personal self-improvement. The courses with the highest opportunity to use were Communication skills, Technical Report writing and Statistics for Agriculture. These courses form the basis of extension work of communicating orally and in writing. Communication is a critical skill in the interaction with farmers and networking with other stakeholders hence the high ratings for Importance and Opportunity of use. Report writing is an important feedback method for projects and programs run by the 
government, funding bodies, NGO's and other stakeholders in agriculture. The move toward pluralistic extension requires greater clarity in communication, accountability and diligence in reporting hence the high Opportunity of Use of technical writing and statistics.

The Mean Weighted Discrepancy Score (MWDS) for basic sciences is represented in the last column (Table 4). The courses with the highest training need were Basic Computer applications, Research Methods and Seminars. The top six basic science courses are all applied science courses in contrast to pure science courses that rank lower. These six courses are interrelated within the communication methods and media and have direct application in written and oral communication. These courses with the highest rankings should be prioritised in in-service staff development courses, curriculum development and review programs. This implies that curricula developers ought to emphasis and integrate these basic and applied science and communication courses in the undergraduate agriculture curriculum.

\subsection{Respondents suggestions on basic science courses to be included or emphasized in the undergraduate agriculture curricula}

This section had open ended question asking respondents to list basic science courses they would require or be emphasized to be included in the undergraduate curriculum. The findings as presented in Table 5. show that basic computer applications, research methods, technical report writing, statistics and communication skills were the most frequently listed courses. This cross validates the MWDS scores that listed these same courses as those with the highest training need (Table 4). The respondents also listed courses that are not basic sciences and these include; HIVIAIDS, Community mobilization, Resource mobilization, Conflict management, Management principles and Government and Institutional management. These are emerging extension management competencies required by extension agents. Extension management courses in undergraduate agricultural programs should therefore cover these competencies and the courses ought to be earmarked for in-service training. (Huerta and Smith, (2001) concur with the findings of this study that although selected agent specialization competencies were perceived as important, the training needs identified included balancing agent specialization with other program responsibilities, making content meaningful, and acquiring in-depth subject matter skills.

Table 4: Respondents training needs in the Basic Sciences

\begin{tabular}{lccccccc}
\hline \multirow{2}{*}{ Basic Sciences } & \multicolumn{2}{c}{ Importance } & \multicolumn{2}{c}{ Knowledge } & \multicolumn{2}{c}{ Opportunity } & \multirow{2}{*}{ MWDS } \\
\cline { 2 - 6 } & $\mathbf{M}$ & $\mathbf{S D}$ & $\mathbf{M}$ & $\mathbf{S D}$ & $\mathbf{M}$ & SD & 6.96 \\
\hline Basic Computer Applications & 4.16 & 1.312 & 2.94 & 1.537 & 3.60 & 1.586 & 4.95 \\
Research Methods & 3.92 & 1.290 & 3.25 & 1.290 & 3.37 & 1.405 & 4.61 \\
Seminars & 4.09 & 1.173 & 3.49 & 1.257 & 3.61 & 1.397 & 4.43 \\
Technical Report Writing & 4.63 & 0.846 & 3.94 & 1.160 & 4.38 & 1.119 & 3.90 \\
Statistics for Agriculture & 3.98 & 1.229 & 3.30 & 1.329 & 3.68 & 1.366 & 3.60 \\
Communication Skills & 4.61 & 0.909 & 4.01 & 1.104 & 4.48 & 1.043 & 3.55 \\
Crop Entomology & 3.71 & 1.370 & 3.19 & 1.356 & 3.37 & 1.496 & 3.08 \\
General Microbiology & 3.30 & 1.379 & 2.90 & 1.312 & 2.92 & 1.420 & 2.83 \\
Basic Biochemistry & 2.79 & 1.308 & 2.56 & 1.228 & 2.34 & 1.291 & 2.70 \\
General Genetics & 3.15 & 1.424 & 3.00 & 1.267 & 2.69 & 1.385 & 2.21 \\
Organic Chemistry & 2.90 & 1.285 & 2.79 & 1.182 & 2.43 & 1.326 & 2.15 \\
General Mathematics & 3.61 & 1.328 & 3.46 & 1.257 & 3.38 & 1.377 & 2.01 \\
General Zoology & 2.60 & 1.363 & 2.56 & 1.263 & 2.30 & 1.295 & 1.92 \\
General Botany & 3.55 & 1.278 & 3.22 & 1.231 & 3.11 & 1.432 & 1.85 \\
Inorganic Chemistry & 2.88 & 1.246 & 2.83 & 1.177 & 2.52 & 1.317 & 1.75 \\
Cell Biology & 2.65 & 1.291 & 2.69 & 1.396 & 2.29 & 1.288 & 1.71 \\
Physical Chemistry & 2.59 & 1.247 & 2.59 & 1.168 & 2.28 & 1.222 & 3.19 \\
\hline Overall mean scores & 3.48 & 1.252 & 3.10 & 1.266 & 3.10 & 1.339 & \\
\hline n = 440 & & & & & & &
\end{tabular}


Table 5: Respondents suggestions of courses for inclusion and emphasis in the Basic Sciences

\begin{tabular}{lcc}
\hline${ }^{*}$ Course & Frequency & Percentage of $\mathbf{4 4 0}$ \\
\hline Basic computer applications & 315 & 71.6 \\
Research methods & 298 & 67.7 \\
Technical report writing & 287 & 65.2 \\
Statistics for agriculture & 245 & 55.7 \\
Community mobilization & 207 & 47.0 \\
HIV/AIDS & 206 & 46.8 \\
Communication skills & 189 & 43.0 \\
Resource mobilization & 156 & 35.5 \\
Conflict management & 111 & 25.2 \\
Management principles & 98 & 22.3 \\
Leadership skills & 67 & 15.2 \\
Government organization and institutional & 57 & 13.0 \\
management & &
\end{tabular}

\subsection{Training needs in Common technical courses}

Common technical courses are agricultural related courses and applied courses from other disciplines that contribute toward understanding of content, context, practice and process of the various disciplines of agriculture such as Agricultural Law and Environmental Science. These courses may be compulsory or optional and Table 6 lists common technical courses taken as complementary courses to the discipline based courses of the various agricultural undergraduate curricula.

The MWDS were all positive with a mean of 3.70. This implies that all the common technical courses were important and the respondents required them for training. This validates their presence in the agricultural undergraduate curriculum. According to the respondents, the three most important common technical courses were Agricultural Law, Field Visits and Extension Education. These courses reflect the competencies that are necessary in the agricultural extension work. The common technical course with the highest knowledge was Field Visits, Field Attachment, Extension Education. The positive knowledge rating reflects the competency level of the respondents and could be an indicator of continuing training in these areas through in-service training and experience particularly for Field Visits and Extension Education that had high importance ratings. The courses with the highest opportunity to use were Field Visit, Extension Education and Soil Conservation and Water Management. These courses reflect the type of extension activities carried out by the respondents. Extension service invariably comprises of field visits and extension education to meet farmer information requirements. Soil Conservation and Water Management has gained increasing importance over the last five years in Kenya due to climate change resulting in extremes of weather reflected in unpredictable rainfall patterns. Kenyan agriculture has been reliant on rain-fed agriculture and farmers are seeking alternatives to rain-fed agriculture, to improve soil fertility and conserve soil moisture (GOK, ASCS Strategy, 2010). This is evident in the increase use of conservation agriculture, green houses, irrigation and the increased use of organic manures.

The MWDS scores are represented in the last column (Table 6). The courses with the highest training need were Agricultural Law, Financial and Human resource management and Rural Development. These three courses did not rank highly for Importance, Knowledge or Opportunity of Use as discussed above and further validates the model ability to derive and prioritise the true training need. Agricultural Law is important in extension work because the decentralization of extension services and pluralistic approach to extension requires institutional and legal commitments, interpretations of agreements among various stakeholders and implications of such agreements invariably mean that extension agents should be familiar with basic concepts of commercial law. The move toward the value chain approach implies that extension agents need to be familiar with local, regional and international law on use of agro-chemicals, trade barriers, tarrifs, quotas, patents and copy-rights, and ways to protect indigenous knowledge and genetic material. Agricultural law is also essential in agricultural research when making commitments to stakeholders and the protection of innovations, farmers' interests and indigenous knowledge (IK).

Agricultural Extension is a people centered service and agriculture is a human driven activity. Understanding of Human Resource Management (HRM) is critical in dealing with farmers and other stakeholders. In particular it is gaining 
importance due to the decentralization of extension activities to district and divisional levels resulting in 20 percent of the respondents engaged in administration and management of extension (Table 3). The management of extension personnel whether technical or support staff has been decentralized therefore issues of staff management, motivation require competencies in HRM. This has been demonstrated earlier in Table 3 where respondents indicated that they supervised a mean of 7.15 people and a maximum of 65 people. Rural development encompasses more than extension education. It is a holistic development perspective of the farming community. The extension agent is no longer restricted to agricultural activities but to the wider context of agriculture (FAO, 2008; GoK, 2010). There is therefore need for more emphasis in systemic interventions to achieve rural development.

Table 6: Respondents training needs in the common technical subjects

\begin{tabular}{lccccccc}
\hline \multirow{2}{*}{ Technical subjects } & \multicolumn{2}{c}{ Importance } & \multicolumn{2}{c}{ Knowledge } & \multicolumn{2}{c}{ Opportunity } & MWDS \\
\cline { 2 - 6 } & $\mathbf{M}$ & SD & $\mathbf{M}$ & SD & M & SD & \\
\hline Agricultural Law & 3.95 & 1.419 & 2.59 & 1.314 & 2.85 & 1.451 & 5.42 \\
Financial and Human resource management & 3.83 & 1.351 & 2.90 & 1.321 & 3.35 & 1.480 & 5.31 \\
Rural Development & 3.73 & 1.372 & 3.10 & 1.384 & 3.42 & 1.467 & 4.05 \\
Principles of Marketing & 3.95 & 1.243 & 3.36 & 1.246 & 3.54 & 1.425 & 4.03 \\
Introduction to Environmental Science & 3.86 & 1.228 & 3.25 & 1.282 & 3.43 & 1.394 & 4.02 \\
Soil conservation and Water Management & 4.09 & 1.246 & 3.54 & 1.246 & 3.68 & 1.446 & 3.94 \\
Farm Structures & 3.52 & 1.411 & 3.10 & 1.318 & 3.09 & 1.476 & 3.93 \\
Research Projects & 3.60 & 1.378 & 3.13 & 1.264 & 3.12 & 1.496 & 3.88 \\
Field Attachment & 3.90 & 1.361 & 3.67 & 1.334 & 3.37 & 1.522 & 3.87 \\
Agricultural experimentation & 3.69 & 1.347 & 3.15 & 1.249 & 3.21 & 1.44 & 3.77 \\
Agricultural Field Machines & 3.27 & 1.413 & 2.76 & 1.325 & 2.86 & 1.428 & 3.73 \\
Introduction to Soil Science & 3.63 & 1.323 & 3.16 & 1.268 & 3.18 & 1.398 & 3.71 \\
Agricultural Economics & 3.94 & 1.204 & 3.40 & 1.204 & 3.58 & 1.343 & 3.66 \\
Rural Sociology & 3.75 & 1.322 & 3.15 & 1.306 & 3.50 & 1.405 & 3.62 \\
Extension Education & 4.17 & 1.168 & 3.70 & 1.235 & 3.92 & 1.377 & 3.41 \\
Field Visits & 4.29 & 1.101 & 3.96 & 1.237 & 4.03 & 1.370 & 3.30 \\
Farm Power Source and Utilisation & 3.16 & 1.393 & 2.75 & 1.316 & 2.79 & 1.429 & 3.20 \\
Livestock practicals & 3.08 & 1.522 & 2.81 & 1.394 & 2.79 & 1.509 & 3.17 \\
Workshop Technology & 2.68 & 1.344 & 2.39 & 1.253 & 2.38 & 1.358 & 2.77 \\
Agro forestry & 3.71 & 1.290 & 3.49 & 1.222 & 3.39 & 1.404 & 2.71 \\
Engineering/technical drawing & 2.51 & 1.333 & 2.33 & 1.244 & 2.26 & 1.339 & 2.30 \\
\hline Overall mean score & 3.61 & 1.322 & 3.13 & 1.284 & 3.23 & 1.427 & 3.70 \\
\hline n = 440 & & & & & & &
\end{tabular}

4.4 Respondents suggestions on common technical courses to be included or emphasized in the undergraduate agriculture curricula

Table 7 presents the common technical courses which were suggested to be included and/or emphasized and include; Report presentation, Field attachment, Agricultural Marketing and Research Methods. These are the felt needs or importance ratings of the respondents. Report presentation is a critical skill in extension communication and in management and had the highest frequency. The frequencies of Field attachment, Agricultural marketing, Research project and Rural Sociology collaborates the MWDS scores depicted in Table 6. Gender mainstreaming in extension ( $f=$ 294) implies that there is need to cover and integrate Gender concepts and perspectives more comprehensively in the undergraduate agriculture curricula. Environmental economics $(f=205)$, Principles of Marketing $(f=117)$, Irrigation and Drainage $(f=97)$ and Biometrics $(f=47)$ indicates the need for greater depth of coverage within the existing courses. 
Table 7: Respondents suggestions of courses for inclusion and emphasis in the Common technical courses

\begin{tabular}{lcc}
\hline Course & Frequency & Percentage of $\mathbf{4 4 0}$ \\
\hline Report presentation & 328 & 74.5 \\
Field attachment & 321 & 73.0 \\
Agricultural marketing & 317 & 72.0 \\
Research project & 316 & 71.8 \\
Mainstreaming gender in extension & 294 & 66.8 \\
Rural sociology & 256 & 58.2 \\
Environmental economics & 205 & 46.6 \\
Organizational development & 184 & 41.8 \\
Office management & 126 & 28.6 \\
Principles of marketing & 117 & 26.6 \\
Irrigation and drainage & 97 & 20.0 \\
Strategic management and innovation & 78 & 17.7 \\
Biometrics & 47 & 10.7 \\
\hline
\end{tabular}

\subsection{Comparison of MWDS ratings of Extension Agents}

The differences in training needs among the respondents were compared in two categories. The first category public or private, was based on the type of extension service offered by the organization the respondents were employed and the second comparison was based on the qualification of the respondents. Subject matter specialists (SMS) who had a minimum degree in an agriculture discipline and Front Line Extension Agents whose highest qualification was a diploma in agriculture discipline. The comparisons were done for each of the three sub sections of the professional core competencies comprised of two sections Basic Sciences and Common technical courses.

The differences in the training needs of professional core competencies were determined using independent sample $t$-test and Mann-Witney $U$ test. The independent sample $t$-test was used to determine if the training needs between staff categories, FEW and SMS and public and private extension service differed significantly or not. The study also used Mann-Witney $U$ test to establish differences in the professional core competencies across staff categories of FEW and SMS; public and private agricultural extension agents. Mann-Witney was used to compare the number of times a score from one of the sample is ranked higher than a score from the other sample. The tables presented in this section summarize the output of the t-test and Mann-Witney $U$ test comparing the professional core competencies in the two categories of respondents.

\subsection{Comparison of MWDS ratings on the Basic Sciences}

Comparison of MWDS on the basic sciences was done in two dichotomies, first for public and private extension service providers and secondly for Subject Matter Specialists (SMS) and Frontline Extension Workers (FEW). The findings are presented in Table 8 and 9. There were no significant differences between the training needs of Public and Private extension agents on the Basic Science courses except for Basic computer applications for which the differences were significant. This shows that extension agents in the public sector had higher training need for Computer applications than did those in the private sector. This could be attributed to the drive to e-government and ICT in the government yet the Private sector had already utilized computers and ICT in its operations and its staff were compliant compared to Public sector where it is being institutionalized. It should be noted that the Standard deviation for the Public sector was large ( $\sigma=6.30$ ) depicting differences in the training needs among the agricultural agents in the Public sector implying that some agents may be computer literate while others required training.

A similar trend can be observed in Table 9 whereby there were no significant differences observed between the MWDS ratings of SMS and FEW on the Basic Sciences except in Basic Computer Applications. FEW's had a higher training need than did the SMS who probably had undergone Basic Computer courses during the Undergraduate training but more so that the nature of work as trainers and administrators requires them to acquire ICT skills and may have undergone in-service courses in ICT. Although the MWDS ratings for FEWs were higher significantly, the MWDS ratings for SMS were still high indicating they still required training in Basic computer applications. This is further supported by the relatively high Standard deviations (FEW: $\sigma=6.53$; SMS: $\sigma=5.09$ ). 
Table 8: Comparison of MWDS ratings on the Basic Sciences for Public and Private Extension Agents

\begin{tabular}{|c|c|c|c|c|c|c|c|c|c|c|}
\hline \multirow[b]{2}{*}{ Basic Science } & \multicolumn{2}{|c|}{ MWDS } & \multicolumn{2}{|c|}{ Std. Dev } & \multicolumn{2}{|c|}{$\mathrm{n}$} & \multirow[b]{2}{*}{$t$} & \multirow{2}{*}{$\begin{array}{c}\text { Sig. } \\
\text { (2-tailed) }\end{array}$} & \multirow{2}{*}{$\begin{array}{c}\text { Mann- } \\
\text { Witney U } \\
\text { test } \\
\text { Z statistic }\end{array}$} & \multirow{2}{*}{$\begin{array}{c}\text { Asymp. } \\
\text { Sig. } \\
\text { (2- } \\
\text { tailed) }\end{array}$} \\
\hline & Public & Private & Public & Private & Public & Private & & & & \\
\hline General Botany & 1.82 & 2.20 & 3.68 & 3.77 & 325 & 115 & -.948 & .343 & -1.010 & 0.312 \\
\hline Organic Chemistry & 2.10 & 2.51 & 3.39 & 3.47 & 210 & 79 & -.908 & .365 & -1.090 & 0.276 \\
\hline Inorganic Chemistry & 1.88 & 1.77 & 3.81 & 3.52 & 195 & 66 & .224 & .823 & -0.072 & 0.943 \\
\hline Physical Chemistry & 1.65 & 1.88 & 3.79 & 4.70 & 210 & 77 & -.434 & .665 & -0.294 & 0.769 \\
\hline General Mathematics & 2.31 & 1.85 & 4.40 & 5.10 & 196 & 72 & .713 & .476 & -1.419 & 0.156 \\
\hline General Genetics & 2.94 & 2.05 & 4.53 & 4.56 & 206 & 75 & 1.447 & .149 & -1.887 & 0.059 \\
\hline General Zoology & 2.13 & 1.60 & 4.06 & 4.20 & 191 & 58 & .859 & .391 & 0.248 & 0.248 \\
\hline Crop Entomology & 3.48 & 3.77 & 4.58 & 4.48 & 197 & 68 & -.457 & .648 & 0.911 & 0.911 \\
\hline General Microbiology & 3.04 & 3.19 & 4.33 & 3.96 & 203 & 73 & -.259 & .796 & 0.512 & 0.512 \\
\hline Cell Biology & 1.98 & 1.05 & 4.95 & 3.73 & 205 & 68 & 1.415 & .158 & 0.319 & 0.319 \\
\hline Basic Biochemistry & 2.81 & 2.87 & 4.71 & 5.42 & 205 & 72 & -.083 & .934 & -0.590 & 0.556 \\
\hline Communication Skills & 3.49 & 3.92 & 4.28 & 4.33 & 187 & 64 & -.692 & .490 & -0.722 & 0.471 \\
\hline Statistics for Agriculture & 3.73 & 4.40 & 4.66 & 4.15 & 204 & 72 & -1.086 & .278 & -1.381 & 0.167 \\
\hline Basic Computer Applications & 7.56 & 4.69 & 6.30 & 4.67 & 225 & 60 & 3.295 & $.001^{*}$ & -2.829 & $0.005^{*}$ \\
\hline Technical Report Writing & 4.45 & 4.37 & 4.81 & 4.70 & 186 & 57 & .107 & .915 & -0.182 & 0.856 \\
\hline Research Methods & 4.97 & 4.88 & 5.43 & 4.67 & 225 & 52 & .118 & .906 & -0.124 & 0.901 \\
\hline Seminars & 4.92 & 3.61 & 5. 46 & 4.75 & 203 & 62 & 1.693 & .092 & -1.890 & 0.059 \\
\hline
\end{tabular}

Table 9: Comparison of MWDS ratings on the Basic Sciences for FEW and SMS

\begin{tabular}{|c|c|c|c|c|c|c|c|c|c|c|}
\hline \multirow{2}{*}{ Basic Sciences } & \multicolumn{2}{|c|}{ MWDS } & \multicolumn{2}{|c|}{ Std. Dev } & \multicolumn{2}{|c|}{$\mathrm{n}$} & \multirow[b]{2}{*}{$t$} & \multirow{2}{*}{$\begin{array}{c}\text { Sig. } \\
\text { (2-tailed) }\end{array}$} & \multirow{2}{*}{$\begin{array}{c}\text { Mann-Witney } \\
\text { U test } \\
\text { Z statistic }\end{array}$} & \multirow{2}{*}{$\begin{array}{c}\text { Asymp. Sig. } \\
\text { (2-tailed) }\end{array}$} \\
\hline & FEW & SMS & FEW & SMS & FEW & SMS & & & & \\
\hline General Botany & 1.85 & 2.04 & 3.96 & 3.26 & 211 & 169 & -.517 & .605 & -1.255 & 0.210 \\
\hline Organic Chemistry & 2.01 & 2.52 & 3.58 & 3.12 & 176 & 113 & -1.233 & .219 & -1.742 & 0.082 \\
\hline Inorganic Chemistry & 1.92 & 1.76 & 4.06 & 3.17 & 161 & 100 & .338 & .736 & -0.355 & 0.723 \\
\hline Physical Chemistry & 1.92 & 1.35 & 4.20 & 3.79 & 176 & 102 & 1.124 & 262 & -0.744 & 0.455 \\
\hline General Mathematics & 2.32 & 1.97 & 4.72 & 4.40 & 167 & 101 & .607 & .544 & -0.577 & 0.564 \\
\hline General Genetics & 2.36 & 3.27 & 4.57 & 4.47 & 174 & 107 & -1.633 & .104 & -1.952 & 0.051 \\
\hline General Zoology & 1.71 & 2.56 & 3.92 & 4.38 & 163 & 86 & -1.561 & .120 & -1.672 & 0.095 \\
\hline Crop Entomology & 3.52 & 3.60 & 4.6 & 4.38 & 154 & 111 & -.135 & .893 & -0.572 & 0.566 \\
\hline General Microbiology & 3.06 & 3.12 & 4.48 & 3.78 & 175 & 101 & -.111 & .912 & -0.395 & 0.693 \\
\hline Cell Biology & 1.83 & 1.61 & 4.91 & 4.33 & 168 & 105 & .370 & .712 & -0.250 & 0.803 \\
\hline Basic Biochemistry & 2.76 & 2.94 & 5.07 & 4.59 & 178 & 99 & -.298 & .766 & -0.754 & 0.451 \\
\hline Communication Skills & 3.59 & 3.62 & 4.38 & 4.17 & 149 & 102 & -.049 & .961 & -0.155 & 0.877 \\
\hline Statistics for Agriculture & 3.84 & 4.00 & 4.78 & 4.14 & 168 & 108 & -.282 & .778 & -0.463 & 0.643 \\
\hline $\begin{array}{l}\text { Basic Computer } \\
\text { Applications }\end{array}$ & 7.56 & 5.88 & 6.53 & 5.09 & 183 & 102 & 2.248 & $.025^{\star}$ & -1.951 & 0.051 \\
\hline Technical Report Writing & 4.01 & 5.13 & 4.55 & 5.07 & 152 & 91 & -1.787 & .075 & -1.671 & 0.095 \\
\hline Research Methods & 5.05 & 4.79 & 5.71 & 4.50 & 175 & 102 & .381 & .703 & -0.079 & 0.937 \\
\hline Seminars & 4.70 & 4.46 & 5.55 & 4.92 & 170 & 95 & .350 & .727 & -0.191 & 0.848 \\
\hline
\end{tabular}

\subsection{Comparison of MWDS ratings on the Common Technical Courses}

Table 10 presents the comparisons of MWDS ratings for Common Technical Courses for Agricultural agents in the Public and Private Sector. There were significant differences in the MWDS ratings of Public and Private Extension Agents in the following courses; Agricultural Economics, Principles of Marketing, Engineering/Technical Drawing and Workshop Technology. In all the courses the Public sector had higher MWDS ratings indicating a greater training need than those from the Private sector. The courses could be grouped in two; one on Agricultural economics and the other in Agricultural engineering. Agricultural economics and Principles of Marketing are of particular interest in light of the program on Kilimo Biashara and the move toward commercialization of agriculture and commodity based approach to Agriculture and the 
emphasis on Commodity Based Value links could explain the importance of these courses among the Public sector extension agents (GoK, 2004; GoK, 2010). Agricultural and Technical drawing and Workshop technology are critical skills in helping farmers design simple farm structures such as a Mushroom room, milking unit, or bee hives. The importance of these courses is an indicator of the functional interface between Public agricultural extension agents and farmers as opposed to the private sector.

A comparison of the MWDS ratings of Common Technical subjects for FEW and SMS is presented in Table 11. Significant differences in the MWDS ratings are observed for Field Attachment, Engineering/Technical drawing and Extension Education. The MWDS ratings are surprisingly higher for SMS than for FEW contrary to expectation that FEW having a diploma in agriculture would have higher training needs as opposed to SMS who have a minimum of a degree. This could be attributed to the nature of work as trainers who require more technical knowledge in the courses to effectively backstop the FEWs. This finding confirms the MWDS ratings of Engineering/technical drawing and Workshop Technology (Table 6) in which the Public sector had higher training need than the Private sector and the technical demands of farmers.

Table 10: Comparison of MWDS ratings on the Common Technical Courses for Public and Private Extension Agents

\begin{tabular}{|c|c|c|c|c|c|c|c|c|c|c|}
\hline \multirow{2}{*}{ Common Technical Courses } & \multicolumn{2}{|c|}{ MWDS } & \multicolumn{2}{|c|}{ Std. Dev } & \multicolumn{2}{|c|}{$\mathrm{n}$} & \multirow{2}{*}{$t$} & \multirow{2}{*}{$\begin{array}{c}\text { Sig. } \\
\text { (2-tailed) }\end{array}$} & \multirow{2}{*}{$\begin{array}{c}\text { Mann-Witney } \\
\text { U test } \\
\text { Z statistic }\end{array}$} & \multirow{2}{*}{$\begin{array}{c}\text { Asymp. } \\
\text { Sig. } \\
\text { (2-tailed }\end{array}$} \\
\hline & Public & Private & Public & Private & Public & Private & & & & \\
\hline Agricultural Experimentation & 3.70 & 4.00 & 4.68 & 5.28 & 230 & 72 & -0.460 & 0.646 & -0.436 & 0.663 \\
\hline Research Projects & 4.12 & 3.07 & 5.03 & 4.84 & 218 & 65 & 1.488 & 0.138 & -1.312 & 0.189 \\
\hline Field Visits & 3.52 & 2.63 & 4.90 & 4.92 & 154 & 50 & 1.111 & 0.268 & -1.305 & 0.192 \\
\hline Field Attachment & 4.23 & 2.73 & 5.11 & 4.59 & 184 & 50 & 2.016 & 0.045 & -1.515 & 0.130 \\
\hline $\begin{array}{l}\text { Introduction to Environmental } \\
\text { Science }\end{array}$ & 4.28 & 3.16 & 5.42 & 4.61 & 215 & 73 & 1.578 & 0.116 & -1.386 & 0.166 \\
\hline Agricultural Economics & 3.91 & 2.20 & 4.18 & 4.99 & 214 & 64 & 2.740 & $0.007^{*}$ & -2.990 & $0.003^{*}$ \\
\hline Principles of Marketing & 4.44 & 2.73 & 4.72 & 4.50 & 204 & 65 & 2.577 & $0.010 *$ & -2.430 & $0.015^{*}$ \\
\hline Introduction to Soil Science & 3.64 & 3.97 & 4.96 & 4.93 & 223 & 57 & -0.449 & 0.654 & -0.011 & 0.991 \\
\hline Farm Structures & 4.24 & 2.97 & 5.65 & 4.31 & 195 & 62 & 1.624 & 0.106 & -1.221 & 0.221 \\
\hline $\begin{array}{l}\text { Soil conservation and Water } \\
\text { Management }\end{array}$ & 3.95 & 3.88 & 4.50 & 4.07 & 210 & 65 & 0.108 & 0.914 & -0.088 & 0.930 \\
\hline Engineering/technical drawing & 2.78 & 0.86 & 4.72 & 3.82 & 201 & 59 & 2.859 & $0.005^{*}$ & -2.697 & $0.007^{*}$ \\
\hline Agro forestry & 2.71 & 2.22 & 4.46 & 4.27 & 194 & 67 & 0.784 & 0.434 & -0.935 & 0.350 \\
\hline Workshop Technology & 3.02 & 1.29 & 4.88 & 4.80 & 196 & 60 & 2.413 & $0.017^{*}$ & -2.914 & $0.004^{*}$ \\
\hline Livestock practicals & 3.44 & 2.52 & 5.62 & 4.78 & 196 & 64 & 1.178 & 0.240 & -0.707 & 0.430 \\
\hline Extension Education & 3.28 & 3.88 & 4.82 & 5.42 & 191 & 53 & -0.780 & 0.436 & -0.734 & 0.458 \\
\hline Rural Development & 4.13 & 3.80 & 5.09 & 5.02 & 213 & 50 & 0.419 & 0.676 & -0.492 & 0.659 \\
\hline Rural Sociology & 3.76 & 3.12 & 4.81 & 4.27 & 216 & 57 & -0.905 & 0.366 & -0.635 & 0.526 \\
\hline Farm Power Source and Utilisation & 3.08 & 3.70 & 4.59 & 6.24 & 212 & 69 & -0.881 & 0.379 & -0.220 & 0.826 \\
\hline Agricultural Field Machines & 3.82 & 3.50 & 5.25 & 4.30 & 220 & 62 & 0.455 & 0.650 & -0.506 & 0.613 \\
\hline Agricultural Law & 5.67 & 4.51 & 5.56 & 5.61 & 240 & 72 & 1.555 & 0.121 & -1.674 & 0.094 \\
\hline $\begin{array}{l}\text { Financial and Human resource } \\
\text { management }\end{array}$ & 5.47 & 4.76 & 5.09 & 5.31 & 226 & 60 & 0.953 & 0.341 & -1.230 & 0.219 \\
\hline
\end{tabular}

Table 11: Comparison of MWDS ratings on the Common Technical subjects for FEW and SMS

\begin{tabular}{|c|c|c|c|c|c|c|c|c|c|c|}
\hline \multirow{2}{*}{ Common Technical Courses } & \multicolumn{2}{|c|}{ MWDS } & \multicolumn{2}{|c|}{ Std. Dev } & \multicolumn{2}{|c|}{$\mathrm{n}$} & \multirow[b]{2}{*}{$t$} & \multirow{2}{*}{$\begin{array}{c}\text { Sig. } \\
\text { (2-tailed) }\end{array}$} & \multirow{2}{*}{$\begin{array}{c}\text { Mann-Witney } \\
\text { U test } \\
\text { Z statistic }\end{array}$} & \multirow{2}{*}{$\begin{array}{c}\text { Asymp. Sig } \\
\text { (2-tailed) }\end{array}$} \\
\hline & FEW & SMS & FEW & SMS & FEW & SMS & & & & \\
\hline Agricultural Experimentation & 3.83 & 3.68 & 4.92 & 4.69 & 187 & 115 & .263 & .793 & -0.324 & 0.746 \\
\hline Research Projects & 4.25 & 3.26 & 5.32 & 4.36 & 176 & 107 & 1.619 & .107 & -1.455 & 0.146 \\
\hline Field Visits & 3.89 & 2.57 & 5.38 & 4.16 & 113 & 91 & 1.914 & .057 & -1.529 & 0.126 \\
\hline Field Attachment & 3.44 & 4.57 & 5.24 & 4.58 & 151 & 92 & -1.696 & .091 & -2.365 & $0.018^{*}$ \\
\hline $\begin{array}{l}\text { Introduction to Environmental } \\
\text { Science }\end{array}$ & 4.32 & 3.51 & 5.63 & 4.56 & 174 & 114 & 1.285 & .200 & -1.094 & 0.274 \\
\hline Agricultural Economics & 3.74 & 3.17 & 4.61 & 4.11 & 171 & 107 & 1.042 & .298 & -1.087 & 0.277 \\
\hline Principles of Marketing & 4.29 & 3.65 & 5.12 & 4.05 & 159 & 110 & 1.086 & .279 & -1.004 & 0.316 \\
\hline Introduction to Soil Science & 3.71 & 3.71 & 5.29 & 4.41 & 167 & 113 & -.005 & .996 & -0.453 & 0.651 \\
\hline Farm Structures & 3.83 & 4.08 & 5.69 & 4.90 & 152 & 105 & -.362 & .718 & -0.977 & 0.329 \\
\hline
\end{tabular}




\begin{tabular}{|c|c|c|c|c|c|c|c|c|c|c|}
\hline $\begin{array}{l}\text { Soil conservation and Water } \\
\text { Management }\end{array}$ & 3.86 & 4.06 & 4.68 & 3.93 & 167 & 108 & -.375 & .708 & -0.668 & 0.504 \\
\hline Engineering/technical drawing & 1.96 & 2.96 & 4.73 & 4.32 & 162 & 98 & -1.708 & .089 & -2.348 & $0.019 *$ \\
\hline Agro forestry & 2.48 & 2.73 & 4.31 & 4.56 & 155 & 106 & -.442 & .659 & -0.091 & 0.927 \\
\hline Workshop Technology & 2.48 & 2.82 & 4.57 & 5.40 & 154 & 102 & -.534 & .594 & -0.084 & 0.933 \\
\hline Livestock practicals & 3.17 & 3.27 & 5.73 & 4.95 & 159 & 101 & -.148 & .882 & -0.733 & 0.464 \\
\hline Extension Education & 3.06 & 3.83 & 5.41 & 4.31 & 135 & 109 & -1.212 & .227 & -2.014 & $0.044^{*}$ \\
\hline Rural Development & 4.38 & 3.59 & 5.43 & 4.41 & 160 & 103 & 1.229 & .220 & -0.776 & 0.438 \\
\hline Rural Sociology & 3.81 & 3.35 & 4.91 & 4.39 & 161 & 112 & .796 & .427 & -0.435 & 0.664 \\
\hline $\begin{array}{l}\text { Farm Power Source and } \\
\text { Utilisation }\end{array}$ & 3.61 & 2.63 & 5.57 & 4.01 & 173 & 108 & 1.598 & .111 & -0.596 & 0.554 \\
\hline Agricultural Field Machines & 3.41 & 4.25 & 5.28 & 4.68 & 168 & 114 & -1.371 & .172 & -1.729 & 0.084 \\
\hline Agricultural Law & 5.03 & 5.97 & 5.68 & 5.40 & 189 & 123 & -1.456 & .146 & -1.506 & 0.132 \\
\hline $\begin{array}{l}\text { Financial and Human } \\
\text { resource management }\end{array}$ & 5.35 & 5.28 & 5.16 & 5.11 & 177 & 109 & .115 & .908 & -0.241 & 0.810 \\
\hline
\end{tabular}

\section{Conclusions and recommendations}

All the basic sciences and common technical courses had positive MWDS indicating that they were all relevant and required for effective extension work. However the indication of a training need points to a need for further analysis in terms of content depth, scope, teaching methodology and integration of knowledge, skills and attitudes throughout the curriculum to develop the desired competencies. These expressed needs cannot be acquired in a single course but requires that competency is developed with continued use of the skill and therefore should be inbuilt into exiting courses, assignments and projects that require students to apply these skills throughout undergraduate agriculture curricula.

The training needs in the basic and core technical courses can be grouped in five categories; Communication and ICT, Extension education, Extension management, Agricultural Economics and Agricultural Engineering. It is therefore recommended that these courses be reviewed, integrated and prioritised in the undergraduate agricultural curricula and in the design of in-service staff development courses.

\section{References}

Bazik, M., and Feltes D. (1999). Defining your Customer Profile- an Essential Tool. Journal of Extension, 37 (6).

Bowe, S., Smith, R., Massey, R., and Hansen, E. (1999). A methodology for determining Extension Constituent Needs: A case Analysis in the Forest Products Industry. Journal of Extension, 37 (4)

Cohen, L. and Manion, L. (1989). Research Methods in Education. $3^{\text {rd }}$ Edition, Routledge, London.

Crowder, V.L, Lindley, W.I, Bruening, T.H and Doron, N. (1999). Agricultural Education for Sustainable Rural Development: Challenges for Developing Countries in the $21^{\text {st }}$ Century, FAO Research, Extension and Training Division, SD Dimensions, Rome.

Edwards, C.M. and Briers, G.E. (1999). Assessing the In-service Needs of Entry-Phase Agriculture Teachers In Texas: A Discrepancy Model Versus Direct Assessment. Journal of Agricultural Education. 40(3): 40-49.

Egerton University. (1999). Egerton University Catalogue 1999/2000. Egerton University, Njoro.

University of Nairobi (2008). University of Nairobi Catalogue. University of Nairobi, Nairobi

Food and Agriculture Organization. (1991). Higher education in agriculture: status, issues and ideas for the future development. Expert consultation on strategy options for higher agricultural education. Rome, FAO.

Food and Agriculture Organization. (1996). Human Resources development in Agriculture. Developing country issues. Training for Agriculture and Rural Development. No. 54 FAO Rome Italy.

Foster, R., Bell, L, and Erskine, N. (1995). The Importance of Selected Instructional Areas in the Present and Future Secondary Agricultural Education Curriculum as Perceived by teachers, Principles, and Superintendents in Nebraska. Journal of Agricultural Education 36 (3): 1 7.

Gagne, R.M., and Briggs, L. (1979). Principles of instructional design. New York: Holt, Rinehart.

Gibson, J. and Schwarz, M.H. (2010). A Needs Assessment of Aquaculture Extension Agents, Specialists, and Program Administrators in Extension Programming, Journal of Extension, Volume 48, Number 2.

GoK - Government of the Republic of Kenya (2001). National Agricultural Extension Policy-(NAEP) Ministry of Agriculture and Rural Development.

GoK - Government of the Republic of Kenya (2004); Strategy for Revitalizing Agriculture (SRA), 2004-2014. Ministry of Agriculture and Ministry of Livestock and Fisheries development, March, 2004.

GoK - Government of the Republic of Kenya (2005). National Agricultural Sector Extension Policy (NASEP); Ministry of Agriculture; Ministry of Livestock and Fisheries Development and Ministry of Cooperative Development and Marketing. December 2005.

GoK - Government of the Republic of Kenya (2000). National Agriculture and Livestock Extension Programme (NALEP). Government of Kenya.

GoK - Government of the Republic of Kenya (2010). Agricultural Sector Development Strategy. 2010-2020 ASCU; Ministry of Agriculture. 
Graham, D.L. and Anita W. Cooper, A.W. (2001). Competencies Needed to be Successful County Agents and County Supervisors, Journal of Extension, Volume 39, Number 1

Huerta, J.M, and Smith,K.L. (2001). Attitudes of County Extension Agents Toward Agent Specialization in Ohio Journal of Agricultural Education Vol. 35, No. 3

Joerger, M.R. (2002). A Comparison of the In-service Education Needs of Two Cohorts of Beginning Minnesota Agricultural Education Teachers. Journal of Agricultural Education 43 (3): 11-24.

Lentz, M. T. (1983). Needs Assessment and Data Collection. In Mertz R.J. (Ed.) Staff Development, Leadership: A Resource Book, Ohio Department of Education.

Lindley, I.W. (1999). Constraints and Potentials of Training Mid-Career Extension Professionals in Africa Part 1and 2 International Workshop on Innovative Training Program for Mid-Career Agricultural Extension Field Staff in Sub-Saharan Africa, 6-8 July, Addis Ababa, Ethiopia.

Maxwell, R. and Lindley, W. (1999). Toward A Balanced Curriculum. Unpublished discussion paper, FAO, Rome.

Miller, J.P and W. Seller. (1985). Curriculum: Perspectives and practice. Longman publishers

Ministry of Agriculture and Rural Development. (2002). Report on the Rationalizing and Staff Right Sizing. Ministry of Agriculture and Rural Development.

Ministry of Livestock and Fisheries Development. (2004). Human Resource Data. Unpublished Report

Mwangi, G. J \& Asiabaka, C.C. (2001). Needs Assessment in Development Program: Implications for extension Policies. International Journal of Agricultural Development. (2): 65-71.

Neito, R. G., Schaffner, D. and Henderson, J.L. (1997). Examining Community Needs Through A Capacity Assessment. Journal of Extension. Vol. 35(3).

Odhingo, A. P. (1986). A Study of the Perceptions of Agricultural Extension Personnel in Migori District About the Agricultural Certificate Curriculum. Egerton University, Unpublished M.Sc Thesis

Ong'ondo, W. M. (1992). Teacher Education in Agriculture at Egerton University; It's Development Program and Critical Issues. A Paper presented at the $5^{\text {th }}$ meeting of the Committee for Education, February 1992, Mombasa, Kenya, unpublished paper.

Pretty, N. J. (1995). Regenerating Agricultural Policies and Practice for Sustainability and Self-reliance. Earthscan Publications Ltd, London.

Pretty, N.J \& Chambers, R.. (1993). Towards a Learning Paradigm; new Professionalism and Institutions for Sustainable Agriculture. IDS Discussion Paper, IDS, Brighton.

Qamar, M.K. (1997). Status and Constraints of Training of Extension Staff in Africa: An International View International Workshop on Training of Extension Personnel in Africa and Third Informal Consultation of Donors Supporting Agricultural Extension Systems in Africa, 19-24 October, Cape Coast, Ghana.

Radhakrishna, R.B. (2001). Professional Development Needs of State Extension Specialists. Journal of Extension, 39 (5).

Swanson, B.E. (2008). Global Review of Good Agricultural Extension and Advisory Service Practices, Natural Resources Management and Environment Department and Policy Assistance and Resources Mobilization Division Technical Cooperation Department. FAO. Rome.

Tanner, D., and Tanner L.N. (1980). Curriculum development; theory into practice (2 ${ }^{\text {nd }}$ ed.) New York, Macmillan.

Waters, G.R. and Haskell, J.L. (1989). Identifying Staff Development Needs of Cooperative Extension Faculty Using a Modified Borich Needs Assessment Model. Journal of Agricultural Education and Extension, 31(Summer): 26-32.

Williams, S.K.T. (1967). Identification of Professional Training Needs of Agricultural Extension Agents in Western Nigeria as a Basis for Developing a College Training Curriculum. Unpublished PhD Thesis.

Zinna, M.M, Steele R.E., Mattocks D.M., and Naibakelao D. (1997). Responsively reshaping Agricultural Extension and Education Curricula in Universities and Colleges in Sub- Saharan Africa. Proceedings of the 13th AIAEE Conference, Ohio, USA. 